\title{
MENINGKATKAN PEMAHAMAN KONSEP IPA DAN KETERAMPILAN BERINKUIRI SISWA SEKOLAH DASAR MELALUI PEMANFAATAN BAHAN AJAR BERNUANSA LITERASI SAINS DALAM MODEL PEMBELAJARAN IPA TERPADU
}

\author{
Uus Toharudin \\ Prodi Biologi FKIP Universitas Pasundan Bandung Jl. Tamansari No. 6-8 Bandung \\ e-mail: uustoharudin@unpas.ac.id
}

\begin{abstract}
Abstrak
Studi kuasi ini dilaksanakan di SDN Cihaurgeulis 2 Bandung pada tahun ajaran 2011-2012 dengan tujuan untuk mengkaji pemanfaatan bahan ajar bernuansa literasi sains dalam model pembelajaran IPA terpadu untuk meningkatkan pemahaman konsep IPA dan keterampilan berinkuiri siswa SD khususnya kelas 3. Penelitian ini menggunakan metode kuasi eksperimen dengan disain yang disebut nonequivalent kontrol group design, yang menggunakan satu kelas kontrol dengan pembelajaran konvensional dan satu kelas eksperimen yang menggunakan model pembelajaran IPA terpadu. Hasil penelitian menunjukkan bahwa peningkatan pemahaman konsep IPA ( $\mathrm{N}$-gain $=0,60)$ dan keterampilan berinkuiri $(0,65)$ siswa kelas eksperimen lebih tinggi dibandingkan kelas control dengan $\mathrm{N}$-Gain pemahaman konsep IPA sebesar 0,34 dan $\mathrm{N}$-Gain keterampilan berinkuiri siswa sebesar 0,30. Peningkatan pemahaman konsep IPA dan keterampilan berinkuiri siswa kelas eksperimen selain dipengaruhi oleh model pembelajaran IPA terpadu yang diterapkan, juga dipengaruhi oleh tingkat klasifikasi kemampuan siswa (tinggi, sedang, rendah). Berdasarkan hasil penelitian yang dilakukan, diharapkan agar ada penelitian lanjutan berkenaan dengan pembentukan sikap ilmiah melalui pembelajaran tematik serta penelitian untuk mengembangkan bahan ajar tematik yang memiliki peranan penting dalam keberhasilan siswa dalam pembelajaran.
\end{abstract}

Kata kunci: inkuiri, literasi sains, bahan ajar, IPA terpadu, sikap ilmiah

\begin{abstract}
This quasi-experimental research was conducted at SDN Cihaurgeulis 2 Bandung in the 2011-2012 school year to assess the use of teaching materials with the literacy nuance of Integrated IPA Learning model to improve understanding the concept of IPA and students inquiry skills in third grade in primary school. This research uses a quasi-experimental method with design that is called nonequivalent control group design, using one control class with conventional learning and one experimental class using model of integrated IPA learning. The results showed that the improvement of understanding the concept of IPA $(\mathrm{N}$-gain $=0.60)$ and students' inquiry skills (0.65) in experimental class were higher than in control class with N-Gain understanding concepts of IPA of 0.34 and N-Gain students' inquiry skills of 0.30 . the improvement of understanding the concept of IPA and students inquiry skills of the experimental class, in addition influenced by integrated IPA learning model that was implemented also influenced by the classification level of student ability (high, medium, low). Based on the results of research conducted, it is expected that there is further research regarding the establishment of a scientific attitude through thematic learning and research to develop thematic teaching materials that have an important role in students success in learning.
\end{abstract}

Keywords: inquiry, scientific literacy, teaching materials, integrated IPA, scientific attitude

\section{PENDAHULUAN}

Pembelajaran IPA terpadu merupakan suatu konsep pendekatan belajar mengajar yang melibatkan beberapa bidang studi untuk memberikan pengalaman yang bermakna kepada siswa. Menurut Fogarty (1991) ada 10 macam model pem- belajaran terpadu, yaitu: fragmented (penggalan), connected (keterhubungan), nested (sarang), sequenced (pengurutan), shared (irisan), webbed (jaring laba-laba), threaded (bergalur), integrated (terpadu), immersed (terbenam), dan networked (jaringan kerja). 
Pembelajaran IPA terpadu merupakan pembelajaran model Jaring Laba-laba (Spider Webbed) yang menggunakan pendekatan tematik (Fogarty 1991). Pendekatan ini pengembangannya dimulai dengan menentukan tema tertentu. Setelah tema disepakati, maka dikembangkan menjadi subtema dengan memperlihatkan keterkaitan dengan bidang studi lain. Setelah itu dikembangkan berbagai aktivitas pembelajaran yang mendukung. Tema merupakan pengikat setiap kegiatan pembelajaran baik dalam mata pelajaran tertentu maupun lintas mata pelajaran. Model ini sangat tepat diterapkan di sekolah dasar karena pada umumnya siswa pada tahap ini masih melihat segala sesuatu sebagai satu keutuhan (holistik), perkembangan fisiknya tidak pernah bisa dipisahkan dengan perkembangan mental, sosial, dan emosional, terutama di kelas-kelas awal sekolah dasar (kelas I dan II).

Bahan ajar bernuansa literasi sains adalah bahan ajar yang dikembangkan yang mengimplementasikan hakikat IPA, di dalamnya memuat materi pelajaran, memuat materi sikap dan memuat latihan keterampilan IPA seperti antara lain berlatih mengobservasi, pengaajaran IPA mengkondisikan berbuat dan berpikir.

Pembelajaran IPA terpadu mengintegrasikan beberapa mata pelajaran dalam satu kesatuan yang terikat oleh tema. Penetapan pendekatan tematik dalam pembelajaran di SD dikarenakan perkem-bangan peserta didik pada kelas rendah sekolah dasar, pada umumnya berada pada tingkat perkembangan yang masih melihat segala sesuatu sebagai satu keutuhan (holistik) serta baru mampu memahami hubungan antara konsep secara sederhana (Diknas, 2006). Namun dalam pelaksanaannya, pembelajaran terpadu atau tematik ini masih mengalami masalah dan hambatan. Guru mengalami kesulitan dalam menyusun silabus sesuai dengan Standar Kompetensi (SK) dan Kompetensi Dasar (KD) yang ditetapkan dalam Standar Isi, serta mengalami kesulitan dalam mengalokasikan waktu yang harus dipergunakan dalam seminggu, karena tidak ada ketentuan alokasi waktu untuk setiap tema yang ditetapkan. Penyebab hal ini mungkin dikarenakan guru-guru belum memahami esensi dan praktek pembelajaran tematik dengan baik. Mereka umumnya belum mendapat pelatihan yang cukup memadai dalam pelaksanaan pembelajaran tematik (Puskur, 2007).

Pembelajaran IPA terpadu jika dilaksanakan sesuai dengan prosedur yang benar akan memberikan peluang bagi pengembangan proses pem- belajaran IPA. Hal ini sejalan dengan landasan filosofis pembelajaran terpadu yang berlindaskan paham konstruktivisme yang menyatakan bahwa pembelajaran bermakna dikonstruksi oleh siswa sebagai hasil dari pengalamannya dalam menghadapi lingkungannya, melalui skema atau struktur kognitif yang akan menyatukan pemahaman dunianya (Saunders, 1992). Berdasarkan beberapa hasil penelitian dan fenomena yang terjadi dilapangan, maka diperlukan sebuah penelitian untuk mengetahui penerapan model pembelajaran IPA terpadu dalam menunjang keberhasilan proses pembelajaran khususnya untuk meningkatkan pemahaman konsep IPAdan pemaha-man keterampilan berinkuiri siswa.

Penelitian tentang pembelajaran tematik dilakukan pula oleh Turpin dan Cage (1998) pada siswa kelas VII yang menggunakan kurikulum IPA terpadu. Hasilnya menunjukkan bahwa pembelajaran tematik memberikan kontribusi yang sangat signifikan bagi pencapaian siswa dalam mempelajari sains, kemampuan keterampilan berinkuiri siswa serta kepemilikan sikap ilmiah. Siswa yang belajar menggunakan kurikulum IPA terpadu menun-jukkan hasil belajar yang lebih baik dibandingkan siswa yang tidak menggunakan pembelajaran tersebut. Selain itu penelitian yang dilakukan oleh Hendrawati (2009) dan Susiani (2010) menunjukkan bahwa hasil belajar siswa mening-kat secara signifikan setelah mengikuti pembelajaran terpadu dibandingkan dengan pembelajaran konvensional yang berbasis subject matter.

\section{METODE PENELITIAN}

Penelitian ini menggunakan metode kuasi eksperimen dengan disain yang disebut nonequivalent kontrol group design dengan menggunakan dua kelas yaitu kelas eksperimen dan kelas kontrol. Disain ini memiliki kelompok kontrol namun tidak dapat berfungsi sepenuhnya untuk mengontrol variabel-variabel luar yang mempengaruhi pelaksanaan eksperimen (Sugiyono, 2007). Pertimbangan penggunaan disain ini adalah sulit sekali menemukan kelas yang memiliki karakteristik yang sama persis, baik dari segi kemampuan intelektual (IQ), motivasi /minat belajar IPA, latar belakang siswa, serta faktor-faktor lainnya yang mungkin dapat mempengaruhi proses pembelajaran selama penelitian berlangsung. Sugiyono (2007) mengatakan bahwa pada jenis desain eksperimen ini terjadi pe- 
ngelompokan subjek tidak secara acak. Desain eksperimennya adalah sebagai berikut:

Tabel 1 Disain Penelitian

\begin{tabular}{|c|c|}
\hline Kelas Eksperimen & $\mathbf{O}_{1} \mathbf{X}_{1} \mathbf{O}_{2}$ \\
\hline Kelas Kontrol & $\mathbf{O}_{1} \quad \mathbf{O}_{2}$ \\
\hline
\end{tabular}

Keterangan :

$\mathrm{O}_{1=}$ Tes awal

$\mathrm{O}_{2}=$ Tes akhir

$\mathrm{X}_{1}$ = Perlakuan berupa penerapan pembe-lajaran tematik

Data pada kelas tersebut diperoleh dari hasil tes awal (pretest) dan tes akhir (posttest). Kelas eksperimen menerapkan pembelajaran IPA terpadu model spider webbed, sedangkan kelas kontrol pembelajarannya secara konvensional.

\section{LOKASI DAN SUBJEK PENELITIAN}

Penelitian ini akan dilaksanakan di SDN Cihaurgeulis 2 yang berada di Jalan Surapati No.82 Kota Bandung tahun ajaran 2011-2012.
Pemilihan lokasi penelitian didasarkan pada pertimbangan bahwa di sekolah tersebut belum melaksanakan pembelajaran terpadu secara utuh bahkan cenderung masih bersifat konvensional berbasis mata pelajaran. Subjek dalam penelitian ini yaitu guru kelas III dan siswa kelas III pada SDN Cihaurgeulis 2. Dasar pertimbangan pemilihan kelas III adalah bahwa siswa kelas III diasumsikan sudah memiliki kemampuan dasar membaca, menulis dan berhitung (calistung), dengan demikian diharapkan pada saat penelitian tidak terdapat kendala yang cukup berarti pada saat siswa berinteraksi dengan bahan ajar bernuansa literasi sains. Siswa pada kelas eksperimen dan kelas kontrol kemudian diklasifikasikan berdasarkan kemam-puannya yang terdiri dari siswa yang memiliki kemampuan tinggi, sedang dan rendah. Berikut adalah deskripsi siswa pada kedua kelas berdasarkan klasifikasi tingkat kemampuan siswa.

Tabel 2 Klasifikasi Siswa Berdasarkan Tingkat Kemampuan

\begin{tabular}{|c|c|c|}
\hline Tingkat Klasifikasi & Kelas Eksperimen & Kelas Kontrol \\
\hline Kemampuan Rendah & 6 siswa & 8 siswa \\
\hline Kemampuan Sedang & 23 siswa & 22 siswa \\
\hline Kemampuan Tinggi & 7 siswa & 6 siswa \\
\hline Jumlah siswa & $\mathbf{3 6}$ siswa & $\mathbf{3 6}$ siswa \\
\hline
\end{tabular}

\section{PENGEMBANGAN INSTRUMEN PENELITIAN}

Instrumen dalam pembelajaran terdiri atas: (1) Perangkat Pembelajaran yang merupakan perangkat penelitian Model IPA Terpadu, (2) Penyusunan Bahan ajar bernuansa literasi sains, (3)Tes Keterampilan Berinkuiri, (4) Tes Pemahaman Konsep IPA, (5) Lembar Observasi, dan (6) Lembar Panduan Wawancara.

Seluruh instrumen yang digunakan dalam penelitian ini telah melalui tahapan validasi atau pengujian, baik secara uji empirik di lapangan maupun berdasarkan pertimbangan para ahli. Khusus untuk pengujian instrumen berbentuk tes, validasi empirik memegang peranan yang sangat penting untuk mengetahui tingkat keterandalannya. Tes yang baik biasanya memenuhi kriteria validitas tinggi, reliabilitas tinggi, daya pembeda yang baik, dan tingkat kesukaran yang layak. Pengolahan data hasil uji coba instrumen ini dilakukan dengan menggunakan sebuah software Anates versi 4. Hasil validasi diperoleh kategori memadai

\section{TEKNIK PENGUMPULAN DATA}

Data penelitian yang dikumpulkan terbagi menjadi dua, yaitu 1) data utama yang merupakan data kuantitatif berupa skor tes pemahaman konsep IPA dan skor tes keterampilan berinkuiri siswa pada kedua kelas, 2) data penunjang dikumpulkan adalah data hasil observasi kegiatan pembelajaran yang dilaksanakan pada kedua kelas, yang kemudian dideskripsikan untuk memperoleh gambaran mengenai proses pembelajaran yang berlangsung sehingga dapat memberikan penjelasan mengenai penyebab terjadinya perbedaan perolehan skor siswa sebelum dan sesudah mengikuti kegiatan pembelajaran. Data pendukung lainnya adalah hasil wawancara dengan guru mengenai proses pembelajaran yang dilaksanakan. 


\section{TEKNIK PENGOLAHAN DATA}

Data yang terkumpul dalam penelitian ini berupa data kuantitatif yang diolah dengan teknik perhitungan secara statistik menggunakan program SPSS for windows 12. Peningkatan yang terjadi sebelum dan sesudah pembelajaran dihitung dengan rumus gain faktor ( $N$-Gain) (Meltzer, 2002). Untuk mendeskripsikan hasil penelitian, maka dibutuhkan data pendukung berupa hasil observasi pembelajaran serta hasil wawancara yang dilakukan terhadap guru.

\section{HASIL PENELITIAN \\ 1. Pemahaman Konsep IPA}

Tes pemahaman konsep IPA siswa diberikan kepada siswa kelas eksperimen maupun kelas kontrol, berupa soal tes awal dan tes akhir pemahaman konsep IPA. Berikut ini disajikan diagram perbandingan nilai pemahaman konsep IPA siswa pada kedua kelas.
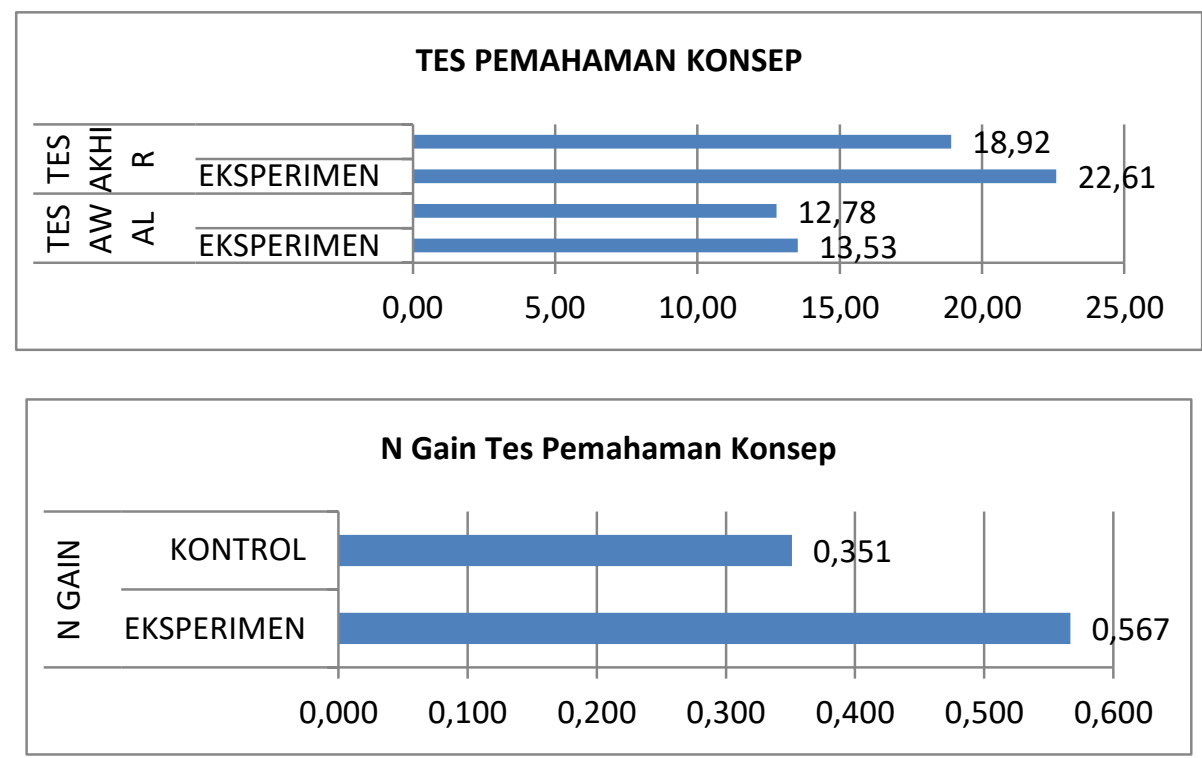

\section{Gambar 1. Diagram Rerata Skor dan N Gain Tes Pemahaman Konsep IPA Siswa} Pada Kedua Kelas

Gambar 1 di atas memberikan gambaran secara umum bahwa sebelum pembelajaran dilaksanakan, kemampuan siswa menjawab tes awal pemahaman konsep IPA pada kelas eksperimen dan kelas kontrol tidak memiliki perbedaan yang yang berarti. Setelah proses pembelajaran hasil rerata tes akhir pemahaman konsep IPA siswa pada kelas eksperimen yang menerapkan pembelajaran tematik menunjukkan peningkatan yang lebih tinggi dibandingkan kelas kontrol dengan indeks $\mathrm{N}$-Gain pemahaman konsep IPA kelas eksperimen $(0,60)$ termasuk dalam kategori sedang (Meltzer, 2002) dan $\mathrm{N}$ Gain pemaha-man konsep IPA kelas kontrol $(0,30)$ termasuk kategori rendah. Hasil pengujian Anova menunjukkan bahwa $\mathrm{N}$-Gain pemahaman konsep IPA pada kedua kelas dipengaruhi oleh (1) model pembelajaran yang diterapkan dan (2) tingkat klasifikasi kemampuan siswa. Berdasarkan uji Befferoni menggunakan SPSS for windows 12 diperoleh hasil bahwa perbedaan tingkat $\mathrm{N}$-Gain terjadi pada setiap tingkat klasifikasi kemampuan siswa pada kedua kelas. Untuk memperjelas gambaran perbedaan rerata $N$-Gain pemahaman konsep IPA pada kedua kelas, dapat dilihat pada diagram berikut ini.

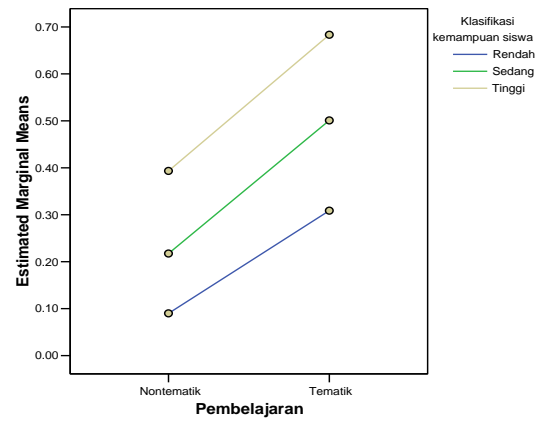

Gambar 2. Diagram estimated marginal means of N-Gain pemahaman konsep IPA 
Hasil pengujian statistik di atas menunjukkan bahwa model pembelajaran tematik lebihefektif meningkatkan nilai pemahaman konsep IPA siswa berkemampuan tinggi dan siswa berkemampuan sedang dibandingkan siswa pada kelas kontrol yang memiliki kemampuan tinggi. Pembelajaran tematik juga lebih efektif dapat meningkatkan nilai pemahaman konsep IPA siswa berkemampuan sedang dan siswa ber-kemampuan rendah pada kelas eksperimen dibandingkan siswa pada kelas kontrol yang memiliki kemampuan sedang dan kemampuan rendah.

\section{Keterampilan berinkuiri Siswa}

Tes keterampilan berinkuiri diberikan kepada siswa kelas eksperimen maupun kelas kontrol, berupa soal tes awal dan tes akhir pemahaman konsep IPA. Berikut ini disajikan diagram perbandingan rerata nilai keterampilan berinkuiri siswa pada kedua kelas.

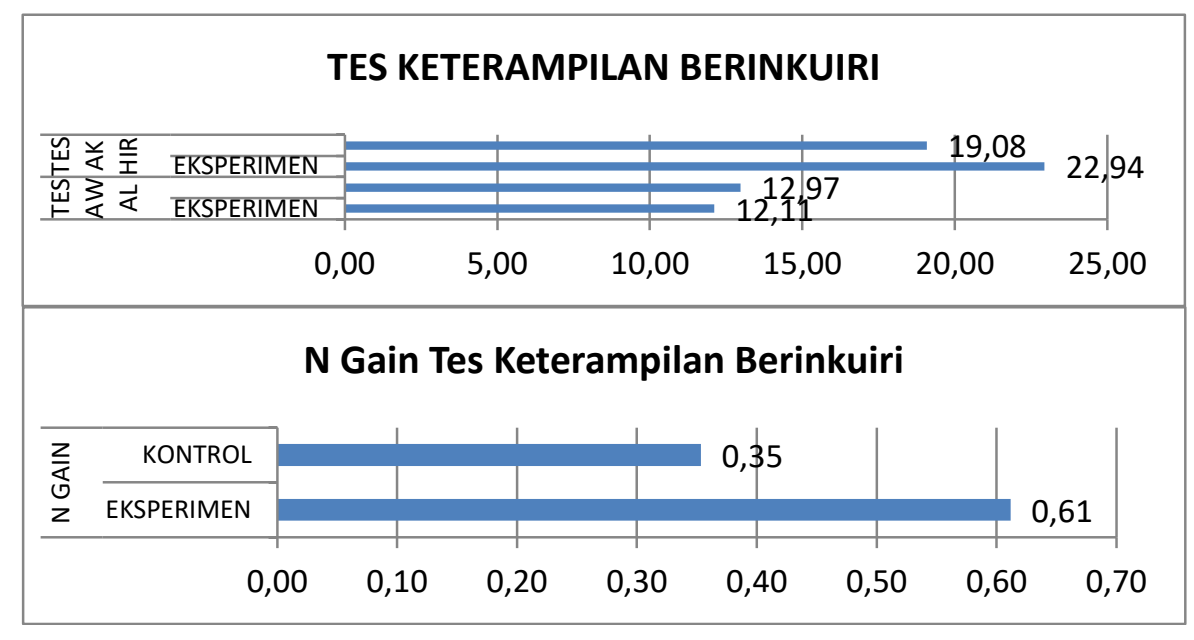

\section{Gambar 3. Diagram rerata skor dan n gain tes keterampilan berinkuiri siswa pada kedua kelas}

Gambar 3 di atas memberikan gambaran secara umum bahwa sebelum pembelajaran dilaksanakan, kemampuan siswa menjawab tes awal keterampilan berinkuiri pada kelas eksperimen dan kelas kontrol tidak memiliki perbedaan yang berarti. Setelah proses pembelajaran hasil rerata tes akhir keterampilan berinkuiri siswa pada kelas eksperimen yang menerapkan pembelajaran IPA terpadu menunjukkan peningkatan yang lebih tinggi dibandingkan kelas kontrol, meskipun indeks $\mathrm{N}$ Gain keterampilan berinkuiri kelas eksperimen dan kelas kontrol termasuk dalam kategori sedang (Meltzer, 2002). Berdasarkan pengujian anova dapat disimpulkan bahwa $N$-Gain keterampilan berinkuiri siswa pada kedua kelas dipengaruhi oleh model pembelajaran yang diterapkan. Namun $N$-Gain keterampilan ber- inkuiri tidak dipengaruhi oleh tingkat klasifikasi kemampuan siswa. Berdasarkan uji Befferoni menggunakan SPSS for windows 12 diperoleh hasil bahwa perbedaan tingkat $N$ Gain terjadi pada setiap tingkat klasifikasi kemampuan siswa pada kedua kelas. Untuk memperjelas gambaran perbedaan rerata $N$ Gain pemahaman konsep IPA pada kedua kelas, dapat dilihat pada diagram (gambar 4) berikut. Hasil pengujian statistik menunjukkan bahwa model pembelajaran IPA terpadu dapat lebih efektif meningkatkan kemampuan pemahaman keterampilan berinkuiri siswa pada kelas eksperimen, baik siswa berkemampuan tinggi, sedang, maupun rendah, bahkan peningkatan siswa berkemampuan rendah di kelas tematik lebih tinggi dari siswa berkemampuan tinggi di kelas non tematik. 


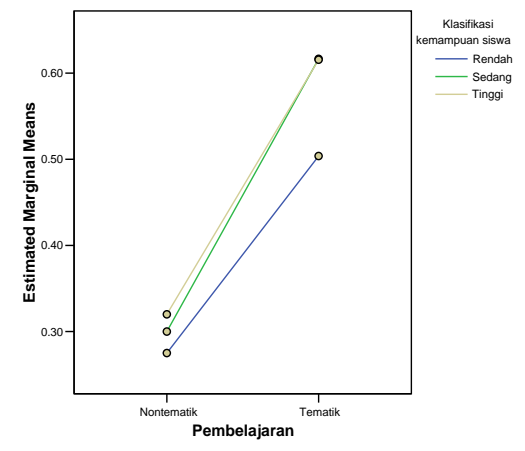

Gambar 4 Diagram Estimated Marginal Means of N-Gain Keterampilan berinkuiri

\section{PEMBAHASAN}

Melalui model pembelajaran IPA terpadu menggunakan bahan ajar bernuansa literasi sains, di mana siswa dapat memperoleh informasi, melaksanakan kegiatan yang dipandu bahan ajar dan pengkondisian sikap melalui bahan ajar, siswa mendapatkan kemudahan mempelajari materi IPA karena dapat dilakukan secara bersamaan saat siswa belajar membaca (pelajaran Bahasa Indonesia). Hal ini nampak dalam proses pembelajaran bahwa materi-materi IPA dijadikan juga sebagai media untuk belajar Bahasa Indonesia. Hal ini menjadi sebuah keuntungan tersendiri bagi siswa bahwa ia mendapatkan dua keuntungan sekaligus, mendapatkan materi IPA dan Bahasa Indonesia dalam waktu yang bersamaan. Hal ini sesuai dengan prinsip dasar pembelajaran terpadu yaitu prinsip the hidden curriculum, dimana pembelajaran yang dikembangkan memuat pesan yang tersembunyi namun penuh makna bagi siswa (Sa'ud, 2006).

Model pembelajaran IPA terpadu mengemas pengalaman belajar yang dirancang untuk memberikan kebermaknaan pengalaman bagi para siswa. Pengalaman belajar yang demikian dapat lebih menunjukkan kaitan unsur-unsur konseptual dan menjadikan proses pembelajaran lebih efektif. Kaitan konseptual yang dipelajari dengan sisi bidang studi yang relevan akan membentuk skema, sehingga anak akan memperoleh keutuhan dan kebulatan pengetahuan. Hal ini senada dengan yang diungkapkan William (Sa'ud, 2006), bahwa perolehan keutuhan belajar, pengetahuan, serta kebulatan pandangan tentang kehidupan dan dunia nyata hanya dapat direfleksikan melalui pembelajaran terpadu. Prinsip-prinsip pembelajaran terpa$\mathrm{du}$, seperti prinsip the learning environment
(Sa'ud, 2006) dalam pembelajaran tematik dilaksanakan untuk menyediakan lingkungan belajar di kelas yang memberikan kebebasan bagi siswa untuk berpikir dan berkreativitas. Kegiatan hands-on (percobaan/praktikum) yang dilakukan secara berkelompok membuat siswa leluasa untuk berinteraksi dengan sesama siswa, dengan guru, bahkan dengan lingkungan. Pembelajaran juga tidak dilakukan secara monoton di dalam kelas, melainkan penuh aktivitas berkelanjutan, dimana siswa bisa keluar masuk kelas untuk mencatat hasil pengamatan bersamaan dengan aktivitas lain yang dilakukan di kelas.

Pembelajaran IPA terpadu beranjak pula dari paham konstruktivisme yang mengarahkan pemahaman yang lebih hakiki dari pengertian IPA dan makna dari pembelajaran IPA itu sendiri. Berbicara tentang IPA berarti berbicara pula tentang proses IPA dengan kata lain IPA adalah proses IPA. Belajar tentang IPA adalah belajar bagaimana menemukan IPA melalui serangkaian proses ilmiah untuk menemukan fakta dan membangun konsep dan prinsip IPA. Pengemasan pembelajaran IPA melalui model pembelajaran tematik ini ditekankan pada keaktifan siswa, sesuai apa yang diungkapkan Yager (Susanto, 2002) bahwa belajar sains dilakukan melalui keaktifan siswa dalam mem-bangun sendiri pengetahuannya, membandingkan informasi baru dengan pemahaman yang telah dimiliki dan menggunakan semua pengetahuan atau pengalaman itu untuk untuk bekerja melalui perbedaan-perbedaan yang ada pada pengetahuan baru dan lama untuk mencapai pemahaman baru. Melalui penerapan model pembelajaran tematik ini, upaya mengkons-truksi pengetahuan dan konsep IPA siswa dilakukan dengan cara menggali pemahaman awal siswa mengenai materi IPA, dalam hal ini tentang matahari. Pertanyaan-pertanyaan yang variatif diajukan guru sebagai apersepsi untuk mengungkap pengetahuan awal siswa. Hal ini sejalan dengan paham konstruktivisme yang berdasarkan pada pada prinsip pengetahuan muncul dan hanya ada dalam pikiran manusia. Dengan demikian perlu disadari bahwa di dalam kelas, pengetahuan hanya ada dalam diri peserta didik dan guru, bukan pada papan tulis dan buku-buku, bukan pada pembicaraan gurumurid atau bukan pula pada aktivitas yang dilakukan mereka. 
Peningkatan perolehan keterampilan berinkuiri siswa pada kelas eksperimen menunjukkan bahwa proses pembelajaran IPA terpadu yang dilakukan dapat membantu siswa mengembangkan aspek-aspek keterampilan berinkuiri yang dimiliki siswa masih harus ditingkatkan melalui pengkondisian bahan ajar yang lebih terarah. Pembelajaran IPA lebih difokuskan pada kegiatan hands-on dan keaktifan siswa dalam mempelajari materi IPA. Hal ini sejalan dengan apa yang diungkapkan oleh Sumantri (2001) bahwa suatu pengajaran yang menggunakan pendekatan keterampilan proses berarti pengajaran itu berusaha menempatkan siswa dalam posisi yang amat penting. Keterampilan proses dapat berkembang pada diri siswa bila diberi kesempatan untuk berlatih menggunakan keterampilan berpikirnya. Dengan keterampilan proses siswa dapat mempelajari IPA sesuai dengan keinginannva. Keterampilan berinkuiri mempunyai cakupan yang sangat luas sehingga aspek-aspek keterampilan berinkuiri sering digunakan dalam beberapa pendekatan dan metode pembelajaran.

Upaya menghadirkan kegiatan-kegiatan yang memberikan nuansa pembelajaran keterampilan proses bagi siswa dalam pembelajaran tematik menekankan usaha-usaha membelajarkan peserta didik bagaimana belajar (to learn how to learn). Usaha ini jelas menuntut keterlibatan peserta didik dalam kadar keterlibatan belajar yang kuat, tinggi, dan maksimal. Oleh sebab itu dalam proses pembelajaran, upaya menumbuh kembangkan keterampilan berinkuiri ini dilakukan juga pada pelajaran lain yang diintegrasikan, baik Matematika, Bahasa Indonesia dan SBK.

Keterpaduan Bahasa, Matematika dan Seni Budaya dan Keterampilan (SBK) dengan IPA dalam pembelajaran IPA terpadu model spider webbed ini telah menghantarkan siswa untuk memiliki pemahaman konsep IPA dan keteram-pilan berinkuiri siswa yang lebih baik pada kelas eksperimen dibandingkan dengan pencapaian siswa pada kelas kontrol. Hal ini tentunya menjadi masukan berharga bagi dunia pendidi-kan bahwa jika prosedur pembelajaran tematik ditempuh dengan cara yang sesuai dengan hakikatnya, maka keberhasilan siswa dalam belajar dapat diraih dengan baik. Pembelajaran tematik yang dilakukan tidak perlu dipaksakan dan diada-adakan, pemilihan konsep dan materi yang sesuai justru akan menjadikan pembelajaran tersebut lebih bermakna bagi siswa. Dukungan yang perlu diberikan pada kelas yang menerapkan pembelajaran tematik adalah perhatian dalam penyediaan sarana dan prasarana pembelajaran yang memadai serta disesuaikan dengan jumlah siswa yang terdapat dalam satu rombongan belajar, seperti yang disyaratkan dalam standar proses Permendiknas No.41 tahun 2007.

\section{KESIMPULAN}

Peningkatan pemahaman konsep IPA siswa yang belajar menggunakan IPA terpadu model spider webbed lebih tinggi dibandingkan siswa yang belajar menggunakan pembelajaran konvensional. Peningkatan pemahaman konsep IPA siswa selain dipengaruhi oleh model pembelajaran yang diterapkan, juga dipengaruhi oleh tingkat klasifikasi kemampuan siswa (tinggi, sedang, rendah).

Peningkatan pemahaman keterampilan berinkuiri siswa yang belajar menggunakan model pembelajaran tematik lebih tinggi dibandingkan siswa yang belajar menggunakan pembelajaran non tematik. Peningkatan pemahaman keterampilan berinkuiri siswa hanya dipengaruhi oleh model pembelajaran tematik yang diterapkan, dan tidak dipengaruhi oleh tingkat klasifikasi kemampuan siswa (tinggi, sedang, rendah).

Proses pembelajaran IPA melalui model pembelajaran tematik dapat dikembangkan lebih efektif dan sesuai dengan karakteristik mata pelajaran IPA yang terdiri atas tiga dimensi yaitu dimensi pengetahuan, proses dan sikap. Pembelajaran tematik ini memberikan peluang bagi siswa untuk belajar IPA lebih banyak dan lebih baik dengan cara berlatih untuk mengembangkan kemampuannya dalam bekerjasama dalam kelompok dan merefleksikan hasil pengalaman belajar mereka di dalam kelompoknya tersebut. Dengan demikian, mata pelajaran IPA dapat dikembangkan bersamasama dengan mata pelajaran lain dalam model pembelajaran tematik.

\section{REKOMENDASI}

Berdasarkan temuan dan hasil penelitian yang diperoleh dalam penelitian ini, maka peneliti menyampaikan saransaran berkaitan dengan penerapan pembelajaran tematik. Saran pertama adalah bahwa pembelajaran 
tematik yang sangat kental dengan aktivitas siswa dalam proses pembelajaran, hendaknya tetap memperhatikan pemahaman konsep siswa terhadap materi yang diajarkan. Sebagaimana diketahui bahwa untuk saat ini teknik penilaian yang dilakukan masih bersifat pengujian terstandar dengan menekankan aspek pemahaman konsep seperti halnya Ujian Akhir Sekolah Berstandar Nasional (UASBN). Oleh sebab itu perlu disiasati upaya pemantapan pemahaman konsep ini dengan upaya drill (latihan) dengan intensitas yang cukup untuk menunjang pemahaman konsep tersebut. Saran kedua adalah bahwa meskipun penekanan utama pembelajaran di kelas rendah (I, II, dan III) adalah pada pemahaman membacamenulis-berhitung (Calistung), namun bukan berarti mengabaikan mata pelajaran lainnya. Oleh sebab itu manfaatkanlah proses pembelajaran Bahasa Indonesia dan Matematika untuk secara bersamaan mengembangkan keterampilan dan pemahaman konsep siswa terhadap materi-materi yang terdapat dalam mata pelajaran lainnya secara bersamaan dalam sebuah keterpaduan yang harmonis dalam pembelajaran. Sebagai saran terakhir, diharapkan agar pada penelitian selanjutnya dikembangkan bahan ajar tematik serta pengembangan materi pembelajaran tematik karena peranannya sangat besar bagi pelaksanaan pembelajaran tematik, baik ditinjau dari sisi siswa dan guru, dan kepentingan peningkatan mutu pendidikan selanjutnya.

\section{DAFTAR PUSTAKA}

Berlin,D.F. (1994). The Integration of Science and Mathematics Education; highlights from NSF/SSMA Wingspread Conference Plenary Papers. Scholl Science and mathematics. 94(1), 3235.

Harlen, Wynne \& Galton,Maurice. (1990) Assessing Science in the Primary Classroom: Observing Activities. London ; Paul Chapman Publishing Ltd.

Charlesworth \& Lind (1999). Math and Science for Young Children, $3^{\text {rd }} \mathrm{Ed}$. Ch.S. Delmar : New York.

Charbonneau, Manon P. (1995). The Integrated Elementary Classroom, a developmental Model of education for the $21^{\text {st }}$ century. United States: A Simon \& Schuster Company.
Collins, Gillian \& Dixon, Hazel. (1991). Integrated Learning; Planned Curriculum Units Australia: Bookshelf Publishing Australia ISBN 0868968447 (Stage 3).

Semiawan, Conny. (1992). Pendekatan Keterampilan Proses, Jakarta:PT Gramedia Widiasarana Indonesia.

Dahar, Ratna Wilis. (1989). Teori-Teori Belajar. Jakarta : Erlangga.

Depdiknas, (2005). Standar Nasional Pendidikan, Jakarta: Peraturan Pemerintah No.19 Tahun 2005.

Depdiknas, (2006). Standar Isi, Jakarta: Permendiknas No. 22 Tahun 2006.

Depdiknas, (2006), Standar Kompetensi Lulusan, Jakarta: Permendiknas No. 23 Tahun 2006.

Depdiknas,(2006). Model Pembelajaran Tematik Kelas Awal Sekolah Dasar. Jakarta: PUSKUR BALITBANG.

Depdiknas, (2006). Pelaksanaan Standar Isi dan Standar Kompetensi Lulusan, Jakarta :Permendiknas No. 24 Tahun 2006 .

Depdiknas, (2006). Pedoman Memilih dan Menyusun Bahan Ajar.

Fogarty, Robin. (1991). The Mindful School. How to Integrate the Curricula. Palatine, Illinois : IRI/Skylight Publishing, Inc

Foulds, William. \& Rowe,John. (1996). The Enhancement of Science Process Skills in Primary teacher Education Students. Australian Journal of Teacher Education Vol.21, No.1,1996.

Hendrawati, S. (2009). Penerapan Pembelajaran Tematik untuk Meningkatkan Penguasaan Konsep IPA dan Keterampilan Proses Sains Peserta didik Sekolah Dasar. Studi Kuasi Eksperimen di SDN Jamika 1 Bandung. Tesis PPs UPI. Bandung: Tidak diterbitkan.

Khisfe, Rola. \& Lederman, Norman. (2006). Teaching Nature Science within a Controversial Topic: Integrated versus Nonintegrated. Dalam Journal of Research in science Teaching Vol.43 No.4 PP 395-418. Tersedia : Willey Inter Science (www.inter-science .wi lley.com).

McBride,J.W \& Silverman,F.L (1992). Integrating elementary/middle school science and mathematics. School 
Science and Mathematics, 91(7), 285292.

Meltzer, David E. (2002). "The Relationship between Mathematics Preparation and Conceptual Learning Gain in Physics: 'hidden variable' in Diagnostic Pretest Scores'. American Journal of Physics, 70, (12), 1259-1267.

Sa'ud, Udin Syaefudin. (2006). Bahan Belajar Mandiri I : Konsep Dasar Pembelajaran Terpadu. UPI: Program Peningkatan Kualifikasi Guru SD/MI Multi sistem .

Sa'ud, Udin Syaefudin. (2006) Bahan Belajar Mandiri III : Jenis Pengembangan Model Pembelajaran Terpadu di Indonesia. UPI: Program Peningkatan Kualifikasi Guru SD/MI Multi sistem .

Sugiyono. (2007). Metode Penelitian Pendidikan, Pendekatan Kuantitatif, Kualitatif, dan $R \& D$, Bandung : Alfabeta.
Sumantri, Mulyani. dan Permana, Djohar. (2001). Strategi Belajar Mengajar. Bandung : CV Maulana.

Susanto, Pudyo. (2002). Keterampilan Dasar Mengajar IPA Berbasis Konstruktivisme. FPMIPA Universitas Malang, Jurusan Biologi.

Tim Pengembang PGSD. (1997). Pembelajaran Terpadu D-II PGSD dan S2 Pendidikan Dasar. Jakarta: Depdikbud Dirjen Pendidikan Tinggi Bagian Proyek Pengembangan PGSD.

Thomas,Julie. (1996), Toward interdisciplinary Math and Science Education : A Literature Riview in Science Education Reform. Paper Presented at AETS Internasional Conference, Seattle, WA, January 11-13,1996, Texas Tech Universty.

Wahana Komputer. (2004). Pengolahan Data Statistik dengan SPSS 12. Yogyakarta : Andi Offset 